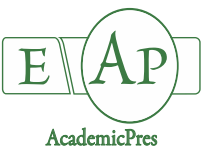

Bozovic D et al. (2020)

Notulae Botanicae Horti Agrobotanici Cluj-Napoca 48(3):1387-1397

DOI: $10.15835 /$ nbha48312058

Research Article

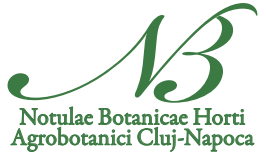

\title{
Stability of the expression of the maize productivity parameters by AMMI models and GGE-biplot analysis
}

\author{
Dragan BOŽOVIĆ ${ }^{1}$, Vera POPOVIĆ ${ }^{2}$, Vera RAJIČIĆ ${ }^{3}$, \\ Marko KOSTIĆ ${ }^{4}$, Vladimir FILIPOVIĆ ${ }^{5}$, Ljubiša KOLARIĆ ${ }^{1}$, \\ Vladan UGRENOVIĆ ${ }^{6}$, Velibor SPALEVIĆ ${ }^{7 *}$ \\ ${ }^{1}$ University of Belgrade, Faculty of Agriculture, Nemanjina 6, 11080 Zemun-Belgrade, \\ Serbia; stragrospancevo@gmail.com; kolaric@agrif.bg.ac.rs \\ ${ }^{2}$ Institute of Field and Vegetable Crops, Institute of National Importance for the Republic of Serbia, Maksim Gorky 30, 21000 Novi \\ Sad,Serbia; vera.popovic@ifvcns.ns.ac.rs \\ ${ }^{3}$ University of Niš, Faculty of Agriculture, Kosančićeva 4, 37000 Kruševac, Serbia; verarajicic@yahoo.com \\ ${ }^{4}$ University of Novi Sad, Faculty of Agriculture, Trg Dositeja Obradovića 8, 21000 Novi Sad, Serbia; markok@polj.uns.ac.rs \\ 5Institute of Medicinal Plant Research, "Dr Josif Pančić, Tadeuša Košćuška 1, 11000 Belgrade, Serbia; vfilipovic@mocbilja.rs \\ 6Institute of Soil, Teodora Drajzera 7, Belgrade, Serbia; vladan.ugrenovic@gmail.com \\ ${ }^{7}$ University of Montenegro, Faculty of Philosophy, Geography, D. Bojovića bb, 81400 Nikšić, Montenegro; \\ velibor.spalevic@gmail.com ("correspondingauthor); stragrospancevo@gmail.com
}

\begin{abstract}
The objective of this study was to estimate genotype by locality, by year, by treatments ( $\mathrm{G} \times \mathrm{LxY} \mathrm{X} T)$ interaction using AMMI model, to identify maize genotypes with stable number of rows of grains performance in different growing seasons. The trials conducted with seven maize lines/genotypes, four treatments, two years and at the two locations. The results showed that the influence of genotype $(\mathrm{G})$, year $(\mathrm{Y})$, locality $(\mathrm{L})$, and $\mathrm{G} \times \mathrm{L}$, $\mathrm{G} \times \mathrm{T}, \mathrm{G} \times \mathrm{L} \times \mathrm{T}, \mathrm{G} \times \mathrm{Y} \times \mathrm{T}, \mathrm{G} \times \mathrm{Y} \times \mathrm{L} \times \mathrm{T}$ interaction on maize number of rows of grains were significant $(\mathrm{p}<0.01)$. The genotype share in the total phenotypic variance for the grains number rows of was $53.50 \%$, and the interaction was $21.15 \%$. The results also show that the sums of the squares of the first and second major components (PC1 and PC2) constitute $100 \%$ of the sum of the squares of the interaction $\mathrm{G} \times \mathrm{L}$. The first PC1 axis belongs to all $100 \%$, which points to the significance of the genotype in the total variation and significance of the genotype for overall interaction with other observed sources of variability. The highest stability in terms of expression of the grains number of rows had the genotype L-6, followed by the genotypes L-4, L-5 and L-3. The lowest stability was demonstrated by the genotypes L- 2 and L-1, which confirmed that these genotypes are not important for further selection in terms of this trait.
\end{abstract}

Keywords: $\mathrm{G} \times \mathrm{Y} \times \mathrm{L} \times \mathrm{T}$ interaction; number of rows of grains; $\mathrm{PCA} 1$ and PCA2; Zea mays

\section{Introduction}

Maize (Zea mays L.) ( $2 n=20)$, belongs to the family Poaceae. Diversified uses of maize worldwide include: grain, starch products, maize oil and forage for animals. Maize in the world sowed of 185 million 
hectares, average yield was $5.62 \mathrm{t} \mathrm{ha}^{-1}$ while total production was over 1.04 billion tonnes. Maize cultivars are grown in approximately 1.10 million hectares annually in Serbia and national average yield was $7.52 \mathrm{t} \mathrm{ha}{ }^{-1}$ (Ikanović et al., 2018). Hybrid seeds demanded by maize growers are provided by mostly national or international seed companies in Serbia.

For a long period, maize breeding has been focused on increased and stabile yield (Babić et al., 2018). Maize breeding programs depend on the understanding and knowledge of genetic diversity and relationship among inbred lines and breeding material. That is especially fundamental in assigning inbreds to heterotic groups and planning outstanding hybrid crosses (Srdić et al., 2007). Maize, according to the sowing area of crops, is on the third place in the world, and on the first place in Serbia. According to the harvested areas, Serbia is the fourth in Europe (Popović, 2010; Ikanović et al., 2018). That is due to the fact that maize has such a versatile usage from the unprocessed product for livestock feed, to that it is processed in many different industries such as food, pharmaceutical and more and more nowadays maize is row material for production of energy. The main goal in production of this crop is achieving high and stabile yields, and recently more and more, higher biomass. Grain yield beside the genetic potential is highly influenced by many factors such as: applied crop practices, soil fertility, and level of ground water, altitude, amount and distribution of precipitation, i.e. conditions of the environment (Branković-Radojčić et al., 2017). Filipović et al. (2015), emphasized that maize breeders are due to the global climatic changes, challenged to create highly adaptable genotypes, which are capable to produce high and stabile grain yields in different environments.

Genotype stability in different environments is the consequence of its genetic structure, but there is a few information about genetic components that determine genotype stability, and how the selection and breeding have the influence on them (Lee et al., 2003). Factors that influence grain yield and thus the economic aspect of maize production are associated with polygene action, but are also under great influence of the environment. In the research of Pavlov and Crevar (2014), it was confirmed that beside the hybrid combination as the major factor, very important influence expressed environmental factors such as years and locations on the parameters of seed production. Therefore, trials in maize breeding process that are focused on grain yield are performed on the larger number of locations and in several successive years. These experiments usually observe the relative success of genotype performances in different environments (Kandus et al., 2010). The aspect of the $\mathrm{G} \times \mathrm{E}$ interaction is very important in breeding programs and as well in the commercial introduction of new hybrids. Deitos et al. (2006) indicate that $\mathrm{G} \times \mathrm{E}$ interaction is important in breeding process because it influences the genetic gain, as well as the recommendation and choosing the varieties with high adaptability. Petrović et al. (2009) concluded that breeding for the targeted environment highly depends on the identification of the major sources of phenotypic variation in that region. In order to develop a variety or a hybrid which possess lower $\mathrm{G} \times \mathrm{E}$ interaction, for the dominant sources of variation, variety should have the balanced proportion between stabile and high yield (Boakyewaa, 2012).

The considerable variation in soil and climate has resulted in large variation in yield performance of maize hybrids annually; thus GEI (genotype x environment interaction) is an important circumstance for plant breeders and agronomists. Evaluation of genotypic performance in a number of environments provides useful information to identify their adaptation and stability (Crossa, 1990). Multi-environment yield trials are used commonly to release superior genotypes for target sites in plant breeding programs. GEI is universal phenomenon when different genotypes are tested in a number of environments. The large GEI variation usually impairs the accuracy of yield estimation and reduces the relationship between genotypic and phenotypic values. GEI due to different responses of genotypes in diverse environments makes choosing the superior genotypes difficult in plant breeding programs (Ilker et al., 2009). Numerous studies on various plant species indicate that the genotype has a contribution about 50\% in realization of yield (Filipović et al., 2015; Živanović et al., 2017; Ikanović et al., 2018).

By using statistical methods, it is possible to exclude the consequences of interaction of genotype and external environment and to isolate stable and high yield genotypes. AMMI model combines the analysis of variance of genotypes and the environment main effects with principal component analysis of the GEI into a 
unified approach (Gauch and Zobel, 1996). However, GGE biplot method, which is always close to the best AMMI models in most cases (Ma et al., 2004), was recently developed to use some of the functions of these methods jointly. It allows visual examination of the relationships among the test environments, genotypes and the genotype by environment interactions (Ding et al., 2007). The differences of the two methods, GGE biplot analysis is based on environment-centred PCA, whereas AMMI analysis is referred to double centred PCA (Ding et al., 2007). AMMI stands for the additive main effect and multiplicative interaction (Gauch, 1992) and GGE biplot stands for genotype main effect plus G×E interaction (Ma et al., 2004).

The aims of this study were to identify superior experimental hybrids with number of rows of grains as well as to select the best location for testing hybrids, year, locations and treatments (with sulfonylurea), developed in the maize breeding program of the domestic company of Serbia by using and comparing AMMI and GGE biplot methods.

\section{Materials and Methods}

\section{Plant material}

The research was carried out at two sites: in Zemun Polje $\left(44^{\circ} 52^{\prime} \mathrm{N}, 20^{\circ} 19^{\prime} \mathrm{E}, 81 \mathrm{~m}\right.$ asl) and in Pančevo $\left(44^{\circ} 52^{\prime} 14^{\prime \prime} \mathrm{N} 20^{\circ} 38^{\prime} 25^{\prime \prime} \mathrm{E}, 77 \mathrm{~m}\right.$ asl) during 2010 and 2011 and the basic plant materials consists of six lines of maize (L-1, L-2, L-3, L-4, L-5 and L-6). The types of soil in Pančevo and Zemun Polje is chernozem. Examines were based on a completely random block system, in three reps, with 20 plants in each repetition. Each genotype was planted in one row with ten houses with two plants each, so that the size of the elementary plot was $2.8 \mathrm{~m}^{2}$ $(0.7 \mathrm{~m} \times 0.4 \mathrm{~m})$. The density of crops was 74.280 plants per hectare. Sowing and harvesting were done manually and, in the experiment, standard maize cultivation technology was applied except for variants with treatment (Božović, 2018; Božović et al., 2018).

\section{Treatments}

The experiments were four sub-treatments with Sulfonylurea herbicides: (1.) $T_{1}$ - Treatment 1; Control was without herbicide treatment was done only with water; (2.) $\mathrm{T}_{2}$ - Treatment 2; active substance Nicosulfuron, and the Motivell preparation in the amount of $1.251 \mathrm{ha}^{-1}\left(6.3 \mathrm{ml}\right.$ per treatment); (3.) $\mathrm{T}_{3}$ Treatment 3; active substance Rimsulfuron, and the Tarot preparation in the amount of $60 \mathrm{~g} \mathrm{ha}^{-1}(0.3 \mathrm{~g}$ per treatment); (4.) $\mathrm{T}_{4}$ - Treatment 4; Active substance Forasulfuron, and the Ekvip preparation in the amount of $2.51 \mathrm{ha}^{-1}(12.6 \mathrm{~mL}$ per treatment).

Herbicides were applied when corn was in the phase of 9-10 developed leaves (15-16 per BBCH scale) with a Solo spiral type with Tee Jet KSR11003, with a water consumption of $2501 \mathrm{ha}^{-1}$. At the time of the technological maturity, at both localities, from each tested genotype, 10 plants from three reps were taken in order to obtain data on the following the number of rows of grains. Biometric data processing is based on repetition for tested trait.

\section{Statistical analysis}

The AMMI model (The Additive Main effects and Multiplicative Interaction) was used to assess the $\mathrm{G} \times \mathrm{E}$ interaction, and it can be represented by the following formula (Gauch and Zobel, 1996): $\mathrm{Y}_{\text {ger }}=$ $\mu+\alpha_{\mathrm{g}}+\beta_{\mathrm{c}}+\Sigma_{\mathrm{n}} \lambda_{\mathrm{n}} \gamma_{\mathrm{gn}} \delta_{\mathrm{en}}+\rho_{\mathrm{gc}}+\varepsilon_{\mathrm{ger}}$

Where: $\mathrm{Y}_{\text {ger }}$ is the yield for the genotype $\mathrm{g}$ in the environment $\mathrm{e}$ the replication $\mathrm{r}$. The additive parameters are: $m-$ the grand mean, $\alpha_{g}-a /$ the genotypic mean deviation from the grand mean, $\beta_{e}-$ the environmental mean deviation. The multiplicative parameters are: $\lambda_{n}-a$ singular value for $n$ interaction principal component axis $n, \gamma_{\mathrm{gn}}-$ the genotypic eigenvector for IPCA axis $n, \delta_{\mathrm{en}}-$ the eigenvector of the environment for IPCA axis $\mathrm{n}, \rho_{\mathrm{ge}}-\mathrm{a}$ residue when not all PCA axis are included and $\mathrm{e}_{\mathrm{ger}}$ - the error. Statistical data analysis was performed 
using the GenStat 12th computer statistical program (GenStat, 2009). AMMI analyses were performed in Excel Biplot Macros (Johnson and Bhattacharyya, 2010).

\section{Meteorological data}

Environmental factors have great influence on qualitative and quantitative traits. The crucial impact on the maize productivity has the amount and the distribution of precipitation (Šarčević-Todosijević et al., 2014; Popović et al., 2016). Maize responds very stressfully to the drought, especially in certain development phases (Popović, 2010; Maksimović et al., 2018). Meteorological data (monthly precipitation and average temperature) were collected from the weather station located near the experimental fields, in Pančevo and Zemun Polje, Serbia. In first year in Pančevo average monthly temperature was $17.44{ }^{\circ} \mathrm{C}$ and in second year $19.53^{\circ} \mathrm{C}$. In Zemun Polje in first year average monthly temperature was $18.51^{\circ} \mathrm{C}$ and in second year $19.57^{\circ} \mathrm{C}$, Figure $1 \mathrm{~A}$.

In first year in Pančevo total amount of precipitation during crop growth cycle was $480 \mathrm{~mm}$ and 497 $\mathrm{mm}$ in Zemun Polje and in second year $368 \mathrm{~mm}$ in Pančevo and $496.60 \mathrm{~mm} 328 \mathrm{~mm}$ in Zemun Polje, Figure $1 \mathrm{~B}$.

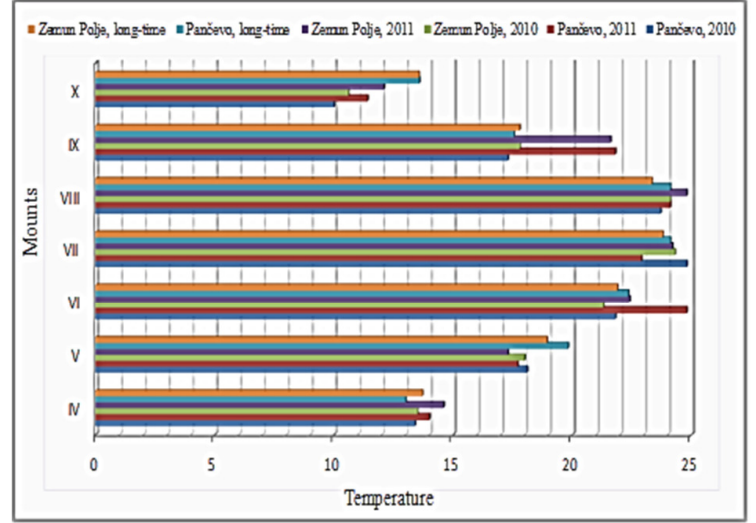

A

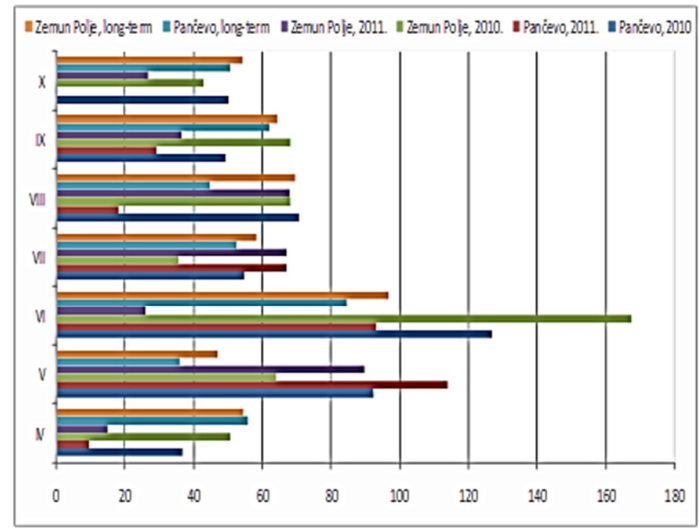

B

Figure 1. This is a figure present meteorological data of tested year

(A) Average temperature, ${ }^{\circ} \mathrm{C}$. (B) Total precipitation, $\mathrm{mm}$ in Pančevo and Zemun Polje, Serbia

\section{Results}

\section{AMMI model for the grains number of rows}

Table 1 shows the analysis of the variance of the AMMI model for the grains number of rows in the investigated maize lines. The degradation of the total sum of the squares to the additive (genetic) and nonadditive (ecological) component by analysing the variance for the number of rows of grains indicates a statistically very significant influence of genotype, year, locality, and statistically significant influence of interactions $\mathrm{G} \times \mathrm{L}, \mathrm{G} \times \mathrm{T}, \mathrm{G} \times \mathrm{L} \times \mathrm{T}, \mathrm{G} \times \mathrm{Y} \times \mathrm{T}$, and $\mathrm{G} \times \mathrm{Y} \times \mathrm{L} \times \mathrm{T}$ (Table 1).

The sums of squares for localities was more than twenty times lower, while sums of squares for years and treatments had more than 100 times lower value than the sum of squares of genotypes. The effect of treatment in total variation is not statistically significant. The genotype share in the total phenotypic variance for number of grain rows was $53.50 \%$, and the interaction was $21.15 \%$. There was a significant difference between the reaction of genotypes to different ecological factors, which results from a large sum of squares of individual interactions, as well as a relatively high share of interactions in the overall variation of this trait. Considering the existence of a significant proportion of the genotype interaction with other sources of variation (years, 
localities and treatments), AMMI analysis of its main components IPCA1 and IPCA2 was done. The first major component, IPCA1, comprised $100 \%$ of the sum of the squared interaction $\mathrm{G} \times \mathrm{L}$ and showed a statistically significant effect, while the share of the second component was $0.00 \%$ and did not show statistical significance. Also, the large sum of the genotype squares indicates a great divergence between the observed genotypes for the observed trait.

Table 1. The additive main effects and multiplicative interactions analysis of variance for number of grains rows for tested maize lines

\begin{tabular}{|c|c|c|c|c|}
\hline \multirow{2}{*}{ Sources of variation } & \multirow{2}{*}{$\mathrm{DF}$} & \multicolumn{3}{|c|}{ Number of rows of maize grains } \\
\hline & & SS & SS (\%) & MS \\
\hline Genotype $(\mathrm{G})$ & 5 & 590.27 & 53.50 & $118.05^{* *}$ \\
\hline Year $(\mathrm{Y})$ & 1 & 5.28 & 0.48 & $5.28^{* *}$ \\
\hline Locality (L) & 1 & 25.09 & 2.27 & $25.09^{* *}$ \\
\hline Treatment $(\mathrm{T})$ & 3 & 3.51 & 0.32 & $1.17^{\mathrm{ns}}$ \\
\hline$G \times Y$ & 5 & 2.91 & 0.26 & $0.58^{\mathrm{ns}}$ \\
\hline $\mathrm{GxL}$ & 5 & 20.27 & 1.84 & $4.05^{* *}$ \\
\hline IPCA1 (100\%) & 5 & 20.3 & 100.00 & $4.05^{\mathrm{ns}}$ \\
\hline IPCA2 $(0 \%)$ & 3 & 0.0 & 0.00 & $0.00^{\mathrm{ns}}$ \\
\hline $\mathrm{G} \times \mathrm{T}$ & 15 & 28.47 & 2.58 & $1.90^{*}$ \\
\hline YxL & 1 & 2.17 & 0.20 & $2.17^{\mathrm{ns}}$ \\
\hline $\mathrm{YxT}$ & 3 & 19.73 & 1.79 & $6.58^{\mathrm{ns}}$ \\
\hline $\mathrm{L} \times \mathrm{T}$ & 3 & 3.20 & 0.29 & $1.07^{\mathrm{ns}}$ \\
\hline GxYxL & 5 & 1.27 & 0.12 & $0.25^{\mathrm{ns}}$ \\
\hline Gx YxT & 15 & 65.66 & 5.95 & $4.38^{* *}$ \\
\hline GxLxT & 15 & 56.02 & 5.08 & $3.73^{* *}$ \\
\hline YxLxT & 3 & 3.51 & 0.32 & $1.17^{\mathrm{ns}}$ \\
\hline GxYxLxT & 15 & 33.97 & 3.08 & $2.26^{*}$ \\
\hline Error & 192 & 242.00 & 21.92 & $1.26^{\mathrm{ns}}$ \\
\hline Total & 287 & 1103.33 & 100.00 & - \\
\hline
\end{tabular}

ns - Non significant; ${ }^{*},{ }^{* *}$ - significant at 0.05 and 0.01

The results also show that the sums of the squares of the first and second major components (PC1 and PC2) constitute $100 \%$ of the sum of the squares of the interaction $\mathrm{G} \times \mathrm{L}$. Also, the first PC1 axis belongs to all $100 \%$, which points to the significance of the genotype in the total variation and significance of the genotype for overall interaction with other observed sources of variability, Table 1.

Genotype by Environment interactions $(\mathrm{G} \times \mathrm{E})$ effects on maize grains number of rows is usually significant due to the diverse environmental conditions at growing sites. The combined ANOVA showed differences among environments $(E)$ and genotypes $(G)$ to be significant indicating that they were diverse. However, genotype by environment interactions for maize grains number of rows was not significant.

Table 2 gives values of IPCAg components of the interaction, that is, the AMMI stability value for the number of rows of grains for tested lines of maize. Lines, L-5, and L-3 are distinguished by minimum values or values that weigh zero for the first main component, IPCAg1, versus the L-6, L-4 and L-2 lines whose values are away from zero. The second IPCAg2 component was zero for all lines, since it was zero in the analysis of the variance.

Stability of maize genotypes 
Stability of the number of grain rows in tested maize lines, observed by location is shown in Figure 2. The highest stability in terms of expression of the number of rows of grains was expressed by the genotype L-3, whose average value for the tested trait almost coincides with the total average for all the genotypes involved in the study. The genotype L-5, which has the best expression of this feature, also features high stability. L-6 and L-4 genotypes have been much less stable, while genotypes L-2 and L-1 are not significant for the process of further refinement in terms of the trait as they have under average expression of the number of rows of grains (Figure 2A).

Table 2. IPCA component of interaction and AMMI value of stability for number of rows of maize grains at examined maize lines

\begin{tabular}{|c|c|c|c|}
\hline \multirow{2}{*}{ Genotype } & \multicolumn{3}{|c|}{ Number of rows of maize grains } \\
\cline { 2 - 4 } & \multirow{2}{*}{ Average } & Genotype x Locality \\
\cline { 2 - 4 } & 10.50 & 0.190 & IPCAg2 \\
\hline L-1 & 10.08 & -0.425 & 0.000 \\
\hline L-2 & 12.10 & 0.036 & 0.000 \\
\hline L-3 & 13.00 & -0.487 & 0.000 \\
\hline L-4 & 13.88 & 0.005 & 0.000 \\
\hline L-5 & 13.42 & 0.681 & 0.000 \\
\hline L-6 & & & 0.000 \\
\hline
\end{tabular}
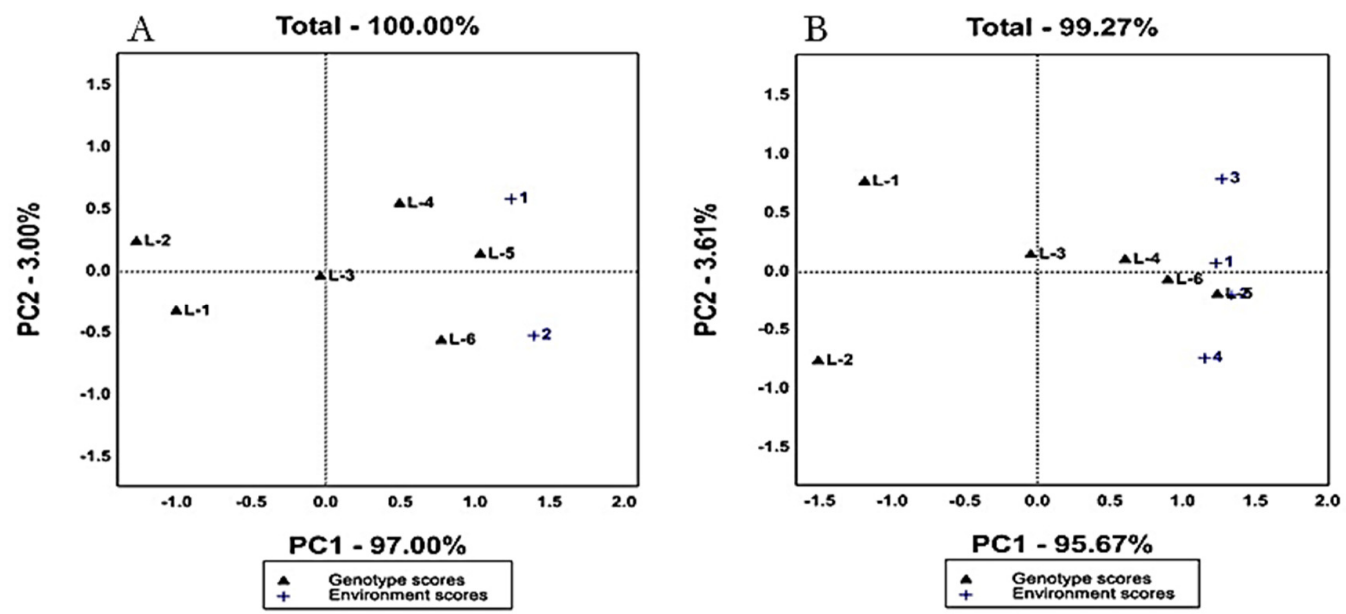

Figure 2. This is a figure, present GGE biplot representation

(A) GGE biplot representation of stability of expression for the number of rows of grain of lines of maize based on locality and (B) based on the treatment

Figure 2B shows stability of the expression of the number of rows of grain at observed lines according to the treatments. It can be concluded that the highest stability in terms of expression of the number of rows of grains had the genotype L-6, followed by the genotypes L-4, L-5 and L-3. The lowest stability was demonstrated by the genotypes L-2 and L-1, which again confirmed that these genotypes are not important for further selection in terms of the trait. It can be concluded that the constant stability of expression of the number of rows of grains has been demonstrated by the genotype L-5, both in terms of the examined locations and the applied treatments. A similar conclusion can be drawn for the genotype L-3, for which can be said that does not represents something new in selection, because its average values are at the average level. 

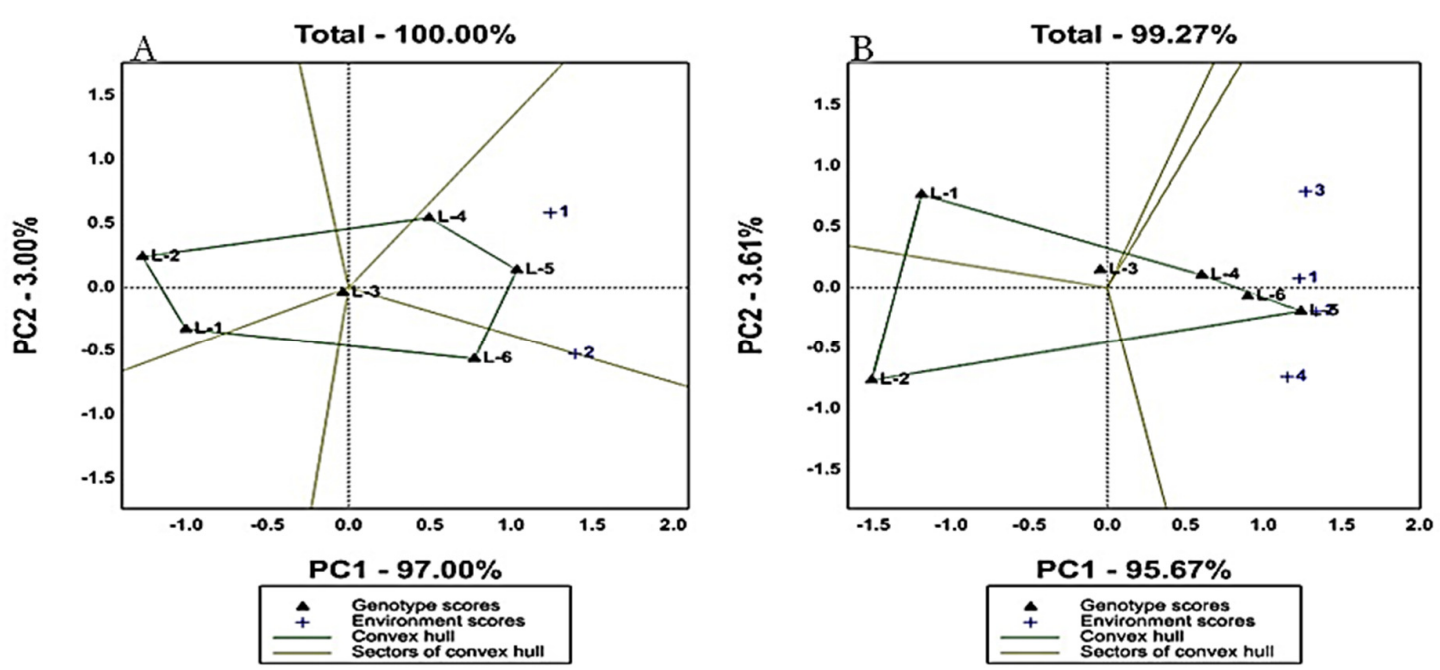

Figure 3. This is (A) figure present GGE-biplot

GGE-biplot view for the number of rows of grain of lines of maize, according to the "which-won-where" model based on the locality and (B) based on the treatment
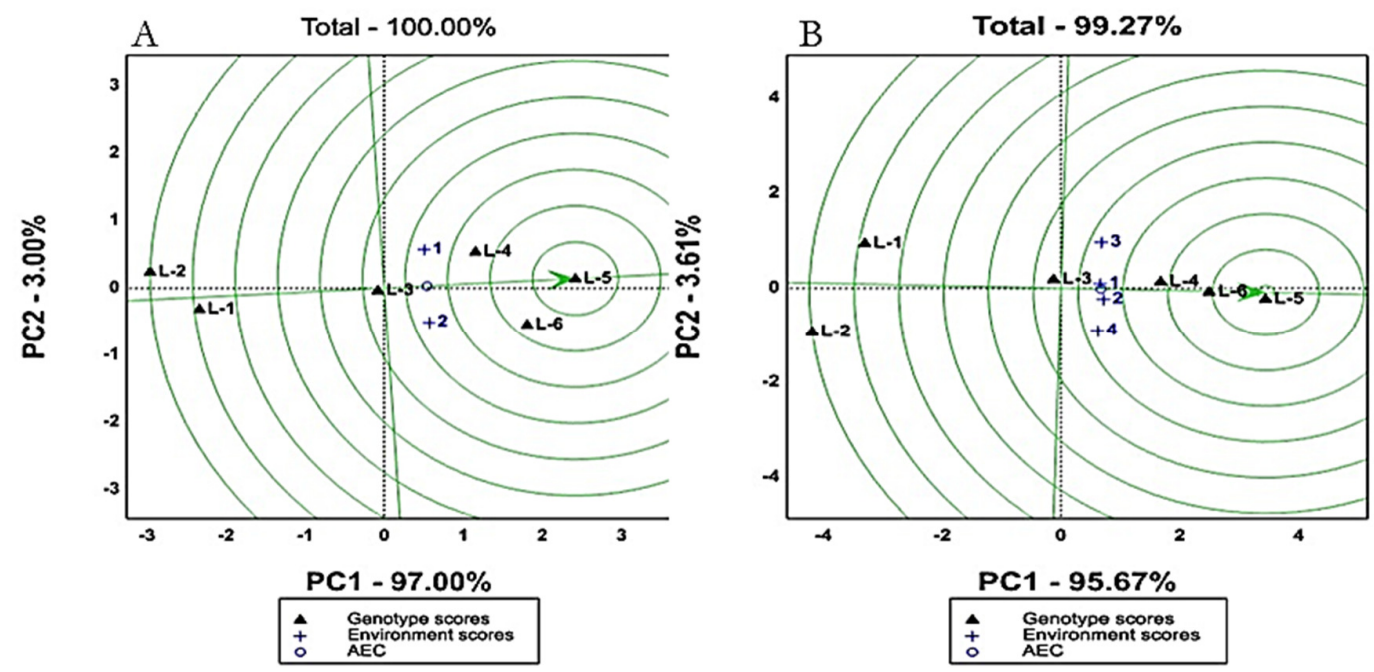

Figure 4. This is (A) figure present GGE-biplot, GGE biplot view for the grain number of rows of maize lines according to the ideal genotype model based on the locality and (B) based on the treatment

In Figure 3A it can be seen that the axes projected from the coordinate start, splits a biplot on 5 sectors. The best expression in locality 1 had genotypes L-5 and L-4. As the value of the locality 2 is at the very border of the two sectors, the phenotypic expression of the mentioned genotypes was high in this locality. The genotype L-6 had good expression only in locality 2 . The other three genotypes did not show a good result in any of the observed localities.

The field of the coordinate system in Figure 3B is divided into four sectors. All treatments and four genotypes are located in one and the largest sector. Based on the phenotypic expression shown for the number of rows of grains, the genotypes L-4, L-5 and L- 6 occupy the same sector on biplot. The mentioned genotypes showed the best values in all examined treatments, which, according to their average values, are also located in the same sector. Genotypes L-1, L-2 and L-3 did not show a good result in the treatment.

Figure 4 shows a comparison of the tested lines with an ideal genotype for expressing the number of rows of grains by locations and treatments. In Figure $4 \mathrm{~A}$ and $4 \mathrm{~B}$ biplot shows that the value of phenotypic expression 
and the stability of the genotype L-5 coincide with the ideal genotype, followed by L-6, L-4, etc. Even in the applied treatments, the genotype L-5 is the closest to the ideal genotype, both in terms of stability and in terms of shown expression. Genotypes L-6 and L- 4 had satisfactory stability but lower expression rates for the observed trait.

\section{Discussion}

The grain number of rows, number of grains per year, mass 100 grains and grain yield belong to the group quantitative properties. Quantitative properties are conditioned by the larger number of genes with bad individual effect i.e. minor genes, for which it is characteristic continuous variability and great ecological variability, which means that the yield does not depend solely of genetic factors but also from factors external environment (Borojević, 1965).

The combined ANOVA showed differences among environments (E) and genotypes $(G)$ to be significant indicating that they were diverse. The proportions of the total variance in grain yield attributable to the environments were the highest (87.27\%) while genotypes and $\mathrm{G} \times \mathrm{E}$ contributed $5.45 \%$ and $0.84 \%$, respectively (Adu et al., 2013).

The nonsignificant $\mathrm{G} \times \mathrm{E}$ interaction effects for grain yield suggests that a promising genotype selected in one of these locations will also be suitable for production in the other locations in the same agro-ecological zone. Environments were found to contribute greatly to the variations in performance of genotypes. This indicates that, unpredictable environmental conditions are one of the major constraints to selecting superior and widely adapted maize varieties. The use of GGE biplot analyses provided clear bases for determining stability and performance of the 100 extra-early maize genotypes (Adu et al., 2013).

Genotypes that in different ecological conditions have the value of the first component close to zero are considered stable. According to Sabaghniaa et al. (2006) genotypes with a minimum variance, as well as a minimum value of IPCg1 axis or when this value of weighting zero in different ecological conditions are considered stable.

Modern plant breeding has been historically oriented toward high agronomic yield rather than the nutritional quality (Morris and Sands, 2006). Such trend indicates that it is necessary to balance between yield and quality in breeding process. Nevertheless, obtained results indicate that OPVs maintained in gene bank, as well as OPVs continuously grown on fields represent potential source for development of good initial material, thus providing grain quality enhancement in white maize breeding collections. The increased incidence of intolerance and allergies to gluten and gluten-containing products has opened up new possibilities for the use of maize flour and maize-based products (Padalino et al., 2011). If adequate measures are applied during cultivation, undesirable effects on OPVs -Open Pollinated Varieties, can be prevented and efficient coexistence of different types of agriculture can be provided (Lorenzana and Bernardo, 2008; Urechean and Bonea, 2017).

AMMI model, GGE model and principal component analysis (PCA) are singular value decomposition (SVD) based statistical analyses often applied to yield-trial data (Gauch, 2006). According to the results of the AMMI and GGE biplot analysis obtained the similar findings from our multi-environment trials data, both of statistical methods can be used reliably by the plant breeders to evaluate maize experimental hybrids and to identify proper test environments.

Maize production is inconceivable without herbicide application, and certainly depends on crop susceptibility. Some injuries could be induced by herbicides, what could result in yield losses. This is especially prominent in maize seed production, due to the line's susceptibility to various stressful conditions, including herbicides. Growing season had significant influence on susceptibility. All applied herbicides from sulfonylurea increased grain yield in 2014, but in 2015 nicosulfuron expressed the lowest selectivity, by decreasing grain yield and soluble proteins up to the 21th day after herbicide application, when compared to control (Dragićević et al., 2017). Genotypes of interest in production are genotypes with high values of the PC1 component when it 
comes to the properties in which the plus variants, i.e. the higher the average value of the tested property and the lower the value of the PC2 component, i.e. close to zero. In the properties in which the minus variants are preferred in the selection process (for example, the height of the stem, etc.), genotypes with a lower PC1 value and a PC2 value tend to be zero, are desirable. Low-grade genotypes PC2 are characterized by broad adaptability, as opposed to specific adaptive genotypes that are located far from the coordinative start. Therefore, the high value of PC2 indicates that the best expression of the trait (Božović et al., 2018) is in specific agro-ecological conditions.

\section{Conclusions}

Results from this study have suggested that AMMI analysis is very applicable for the analysis of maize lines and different years, locality, treatment and their interaction.

The genotype share in the total phenotypic variance for the number of rows of grains was $53.50 \%$, and the interaction was $21.15 \%$. The results also show that the sums of the squares of the first and second major components (PC1 and PC2) constitute $100 \%$ of the sum of the squares of the interaction $\mathrm{G} \times \mathrm{L}$. Also, the first PC1 axis belongs to all $100 \%$, which points to the significance of the genotype in the total variation and significance of the genotype for overall interaction with other observed sources of variability.

Value of phenotypic expression and the stability of the genotype L-5 coincide with the ideal genotype, followed by L-6, L-4, etc. Even in the applied treatments, the genotype L-5 is the closest to the ideal genotype, both in terms of stability and in terms of shown expression. Genotypes L-6 and L- 4 had satisfactory stability but lower expression rates for the observed trait.

\section{Authors' Contributions}

In this research, all authors contributed effectively. VR wrote the manuscript; VP designed the experiments; MK, LJK and DB carried out the experiments; VF and VU analysed the data, VS writing-review \& editing; VP supervised the project and revised the manuscript. All authors have read and agreed to the published version of the manuscript.

\section{Acknowledgements}

Research was supported by the Ministry of Education, Science and Technological Development of the Republic of Serbia (Projects agreement number: 451-03-68/2020-14/200032, 200116, 200117, 200011 and 200003) and bilateral project Montenegro - Serbia; 2019-2020): Alternative cereals and oil crops as a source of healthcare food and an important raw material for the production of biofuel.

The hereby work was accepted and presented at the GEA (Geo Eco-Eco Agro) International Conference 28 May 2020, Podgorica, Montenegro, and it has been published as abstract in "Book of Abstracts" (http://www.gea.ucg.ac.me/page.php?id=64).

\section{Conflict of Interests}

The authors declare that there are no conflicts of interest related to this article. 


\section{References}

Adu GB, Akromah R, Abdulai MS, Obeng-Antwi K, Kena AW, Tengan KML, Alidu H (2013). Assessment of genotype by environment interactions and grain yield performance of extra-early maize (Zea mays L.) hybrids. Assessment 3(12).

Babić V, Kravić N, Živić J, Srdić J, Popović A, Nikolić A, Miritescu M (2018). Grain quality within ex situ and in situ conserved traditional white maize landraces. Romanian Agricultural Research 35:129-140. http://www.incdafundulea.ro/rar/nr35/rar35.17.pdf

Boakyewaa AG (2012). Genotype by environment interaction and grain yield stability of extra early maize (Zea mays L.) hybrids evaluated at three locations in Ghana. PhD Thesis. Faculty of Agriculture, Kwame Nkrumah University of Science \& Technology, Kumasi, Ghana.

Borojević S (1965). Mode of inheritance and heritability of qualitative properties in crossings various varieties of wheat. Contemporary Agriculture 7(8):587-607.

Božović D (2018). Stability of yield and maize compounds in conditions of stress under the sulphonylurea. Doctoral Dissertation, University of Belgrade, Faculty of Agriculture, Belgrade pp 1-205.

Božović D, Živanović T, Popović V, Tatić M, Gospavić Z, Miloradović Z, ... Đokić M (2018). Assessment stability of maize lines yield by GGE-biplot analysis. Genetika 50(3):1-10. https://doi.org/10.2298/GENSR1803755B

Branković-Radojčić D, Srdić J, Milivojević M, Šurlan-Momirović G, Radojčić A, Živanović, T, Todorović G (2017). Variability of agronomic traits of maize hybrids influenced by the environmental factors. Journal on Processing and Energy in Agriculture 21(3): 149-153. http://rik.mrizp.rs/handle/123456789/661

Crossa J (1990). Statistical analysis of multilocation trials. Advances in Agronomy 44:55-85. https://doi.org/10.1016/S0065-2113(08)60818-4

Deitos A, Arnhold E, Miranda GV (2006). Yield and combining ability of maize cultivars under different eco-geographic conditions. Crop Breeding and Applied Biotechnology 6:222-227.

Ding M, Tier B, Yan W (2007). Application of GGE biplot analysis to evaluate genotype (G), environment (E) and Gx E interaction on P. radiata: a case study. Australasian Forest Genetics Conference Breeding for Wood Quality, Tasmania, Australia.

Dragićević V, Simić M, Jovanović-Radovanov K, Brankov M, Srdić J (2017). Reaction of susceptible maize inbred lines to herbicides. Genetika 49(3):765-774. https://doi.org/10.2298/GENSR1703765D

Filipović M, Jovanović Ž, Tolimir M (2015). Direction of selection of new ZP hybrids. XX Conference on Biotechnology. Čačak 20(22):7-13.

Gauch HG (1992). Statistical analysis of regional yield trials: AMMI analysis of factorial designs. Elsevier, Amsterdam, pp 278.

Gauch HG (2006). Statistical analysis of yield trials by AMMI and GGE. Crop Science 46:1488-1500. https://doi.org/10.2135/cropsci2005.07-0193

Gauch HG, Zobel RW (1996). AMMI analysis of yield trials. In: Genotype by Environment Interaction. CRC Press, Boca Raton, FL, pp 85-122.

Ikanović J, Živanović Lj, Popović V, Kolarić Lj, Dražić G, Janković S, Pavlović S (2018). Possibility of greater use of maize as a bioenergy. Institute of PKB Agroekonomik 24(1-2):49-59.

Ilker E, Aykut Tonk F, Çaylak Ö, Tosun M, Özmen L (2009). Assessment of genotype x environment interactions for grain yield in maize hybrids using AMMI and GGE biplot analyses. Turkish Journal of Field Crops 14(2):123135. http://www.field-crops.org/assets/pdf/product541b1a41a6877.pdf

Johnson R, Bhattacharyya G (2010). Statistics, principles and methods. $6^{\text {th }}$ Ed. John Wiley \& Sons.

Kandus M, Almorza D, Boggio Ronceros R, Salerno JC (2010). Statistical models for evaluating the genotype environment interaction in maize (Zea mays L.). Fyton-Revista Internacional de Botanica Experimental 79:39-46. https://pdfs.semanticscholar.org/42f2/188bbd19e489a5bc0ba6de3326db96acad39.pdf

Lee EA, Doerksen TK, Kannenberg LW (2003). Genetics of yield stability in maize breeding populations. Crop Science 43:2018-2027. https://doi.org/10.2135/cropsci2003.2018

Lorenzana RE, Bernardo R (2008). Genetic correlation between corn performance in organic and conventional production systems. Crop Science 48:903-910. https://doi.org/10.2135/cropsci2007.08.0465

Ma BL, Yan W, Dwyer LM, Frégeau-Reid J, Voldeng HD, Dion Y, Nass H (2004). Graphic analysis of genotype, environment, nitrogen fertilizer, and their interaction on spring wheat yield. Agronomy Journal 96:169-180. https://doi.org/10.2134/agronj2004.1690 
Maksimović L, Popović V, Stevanović P (2018). Water and irrigation requirements of field crops grown in central Vojvodina, Serbia. Agriculture and Forestry 64(1):133-144. https://doi.org/10.17707/AgricultForest.64.1.16

Morris CE, Sands DC (2006). The breeder's dilemma-yield or nutrition? Nature Biotechnology 24:1078-1080. https://doi.org/10.1038/nbt0906-1078

Padalino L, Mastromatteo M, Sepielli G, Del Nobile MA (2011). Formulation optimization of gluten-free functional spaghetti based on maize flour and oat bran enriched in $\beta$-glucans. Materials 4:2119-2135. https://doi.org/10.3390/ma4122119

Pavlov M, Crevar M (2014). Effects of agroecological factors and hybrid combinations on seed traits of maize hybrids. Journal on Processing and Energy in Agriculture 18(1):11-13.

Petrović S, Dimitrijević M, Belić M, Banjac B, Vukosavljević M (2009). Spike stability parameters in wheat grown on solonetz soil. Genetika 41(2):199-205. https://doi.org/10.2298/GENSR0902199P

Popović V (2010). Influence of agro-technical and agro-ecological practices on seed production of wheat, maize and soybean. Doctoral dissertation, University of Belgrade, Faculty of Agriculture, Zemun-Belgrade, Serbia pp 1-145.

Popović V, Tatić M, Ikanović J, Drazić G, Mihailović B, Đukić V... Stevanović P (2016). Variability of yield and chemical composition in soybean genotypes grown under different agroecological conditions of Serbia. Romanian Agricultural Research 33:29-39.

Sabaghniaa N, Dehghania H, Sabaghpour B (2006). Nonparametric methods for interpreting genotype $\times$ environment interaction of lentil genotypes. Crop Science 46:1100-1106. https://doi.org/10.2135/cropsci2005.06-0122

Sarcevic-Todosijevic Lj, Zivanovic Lj, Janjic S, Popovic V, Ikanovic J, Popovic S, Drazic G (2016). The influence of nitrogen fertilizer on the total number of microorganisms and amino-autotroph dynamics under 'Ugar' and sown maize. Agriculture and Forestry 62(3):185-196. https://doi.org/10.17707/AgricultForest.62.3.16

Spasojević I, Dragičević V, Simić M, Kovačević D, Brankov M (2014). Effects of different cropping systems and weed management methods on free energy and content of pigments in maize. Pesticidi i Fitomedicina 29(1):45-54. https://doi.org/10.2298/PIF1401045S

Srdić J, Mladenović Drinić S, Pajić Z, Filipović M (2007). Characterization of maize inbred lines based on molecular markers, heterosis and pedigree data. Genetika 39(3):355-363. https://doi.org/10.2298/GENSR0703355S

Urechean V, Bonea D (2017). Coexistence in cultivation of genetically modified maize (MON810) with conventional maize. Romanian Agricultural Research 34:1-8.

Živanović Lj, Savić J, Ikanović J, Kolarić Lj, Popović V, Novaković M (2017). The influence of genotype on wheat, soybean, corn and sunflower grain yield. Jourbnal of Institute of PKB Agroekonomik Belgrade 23:1-2.
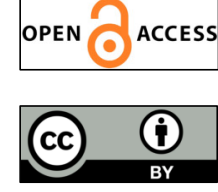

The journal offers free, immediate, and unrestricted access to peer-reviewed research and scholarly work. Users are allowed to read, download, copy, distribute, print, search, or link to the full texts of the articles, or use them for any other lawful purpose, without asking prior permission from the publisher or the author.

License - Articles published in Notulae Botanicae Horti Agrobotanici Cluj-Napoca are Open-Access, distributed under the terms and conditions of the Creative Commons Attribution (CC BY 4.0) License.

(c) Articles by the authors; UASVM, Cluj-Napoca, Romania. The journal allows the author(s) to hold the copyright/to retain publishing rights without restriction. 